\title{
Interpreting transfers of rocks during the Mesolithic in the West of France
}

\author{
Grégor Marchand \\ UMR 6566 CNRS - CReAAH Centre de Recherche en Archéologie Archéosciences Histoire. Campus Beaulieu, \\ Bât 24, 25 - 263 avenue du Général Leclerc, CS 74 205, 35042 RENNES Cedex, France. \\ Email: gregor.marchand@univ-rennes1.fr
}

\begin{abstract}
:
The crystalline geological substratum of the Armorican Massif, in the West of France, is devoid of flint nodules in primary position. As a result, during Prehistory, humans developed different strategies for making their toolkits, either by adapting production methods to local rocks from diverse sources, or by importing materials from the sedimentary margins. This article proposes to analyse the distribution of lithic materials during the Mesolithic as the consequence of a succession of collective choices. Many sedimentary, metamorphic or plutonic rocks of local origin were used, and considerably increased in quantity from the Early Mesolithic to the Late Mesolithic. After the identification of the geological origin of the rocks, a series of mechanical analyses were carried out to define their properties. Then, the social integration process of these rocks was addressed. The lithic assemblages of Beg-er-Vil (Quiberon) and la Presqu'île (Brennilis) were then described to tangibly explain the intentions of productions in coastal and continental economies respectively during the Late Mesolithic (end of the seventh and sixth millennia BCE). The toolkits in both economies are strictly identical, but two different lithic management systems were clearly in place. The first, on the coast, consisted exclusively of production on pebbles, whereas, the other, inland, used a wide range of materials of mediocre quality. During the Mesolithic (and unlike Neolithic practices), and in this context of geological paucity, sacrificing technical standards always seemed preferable to longdistance acquisitions by means of imports or exchanges.
\end{abstract}

Keywords: Armorican Massif; Eocene sandstone; Mesolithic; siliceous shale; ultramylonite

\section{Introduction}

The crystalline geological substratum of the Armorican Massif, in the West of France, is devoid of flint nodules in primary position. As a result, during Prehistory, humans developed different strategies for making their toolkits, either by adapting production methods to local rocks from diverse sources, either by changing their initial aims, or by importing materials from the sedimentary margins. Thus, during the Mesolithic (9500-5000 BCE) or the RecentFinal Neolithic (3500-2300 BCE), certain groups preferred local siliceous rocks, often of rather mediocre quality, at the expense of the metamorphosis of their tools and techniques (Gouletquer et al. 1996; Yven 2004; Marchand \& Tsobgou Ahoupe 2009). Others abandoned

Published by the School of History, Classics and Archaeology, University of Edinburgh ISSN: 2055-0472. URL: http://journals.ed.ac.uk/lithicstudies/ 
their traditional instruments, which were too difficult to make, and developed new tools adapted to the structure and mechanical reactions of the rocks. Conversely, certain Neolithic communities (5000-2300 BCE) established effective flint importation networks over long distances, which enabled them to make toolkits in line with the demanding technical standards applied on the mainland at that time (Guyodo 2001: 45-60; Ihuel 2008: 70-75; Pailler et al. 2008). In parallel, the attraction for metamorphic or plutonic rocks from local substrata for manufacturing axes and ornamental elements, favoured the emergence of long-distance exportation networks, inspired and supplied by value systems and social standing (Querré et al., 2008; Pétrequin et al. 2012: 350).

All these choices in the acquisition of lithic materials enable us to characterize past societies not only in terms of the style or techniques of their tools, but more generally in terms of their economic and social behaviour in a general context of scarcity. These geological constraints and the ways in which they were circumvented clearly had a major impact on the spatial dispersion of lithic tools and waste products. Maps taking this into account can indicate a sort of plurality of interactions between humans and non-humans, or, in other words, they display transfers which are totally dependent on collective choices in line with technical standards. These dispersion areas do not a priori indicate territories claimed by a community, or even areas of collective mobility, but they are the result of all the relationships between human groups, which also include specific geopolitical situations (defined as the study of the relationships between geographical and political data). In this article, we emphasize the concepts and methods developed over the past twenty years in the West of France to analyse and interpret these lithic material distribution maps, focusing in particular on the economies of hunter-gatherers during the Mesolithic.

\section{Geological and mechanical identification of flaked rocks}

\subsection{Creation of geological databases}

Petroarchaeology emerged in the lineage of naturalist approaches and several major research programmes have been conducted in the Armorican Massif (Figure 1) since the 1950s, mostly in the universities of Rennes 1, Nantes, Brest and Paris-Nanterre. They focused on the origin of Neolithic polished axe blades (Giot \& Cogné 1955; Herbaut 2001:36; Le Roux 1999: 140; Pailler 2007: 370; Pétrequin et al. 2012: 25), variscite beads (Querré et al. 2008) or bracelets in schist (Fromont 2006; 2008), but also on endogenous rocks flaked during the Palaeolithic (Huet 2006: 123; Monnier 1980: 80), the Mesolithic (Gouletquer et al. 1996; Marchand \& Tsobgou Ahoupe 2009; Tsobgou Ahoupe 2006; 2007: 89; 2010; Tsobgou Ahoupe \& Dabard, 2010; Yven 2003; 2004: 50), or the Neolithic (Blanchet et al. 2010; Guyodo 2001: 45; Ihuel 2008: 70; Marchand 2009). In the zones neighbouring the massif, petrographic investigations were carried out to provide answers to archaeological questions on the flint sedimentary formations, to the west of the Paris Basin (Charraud 2015; Desloges 1986; Ghesquière et al. 2008; 2012; Marchand et al. 2009), in the Aquitaine Basin (Fouéré 1994: 55-112) and in the Seuil du Poitou (Cordier 1998; Primault 2003; 2012). 


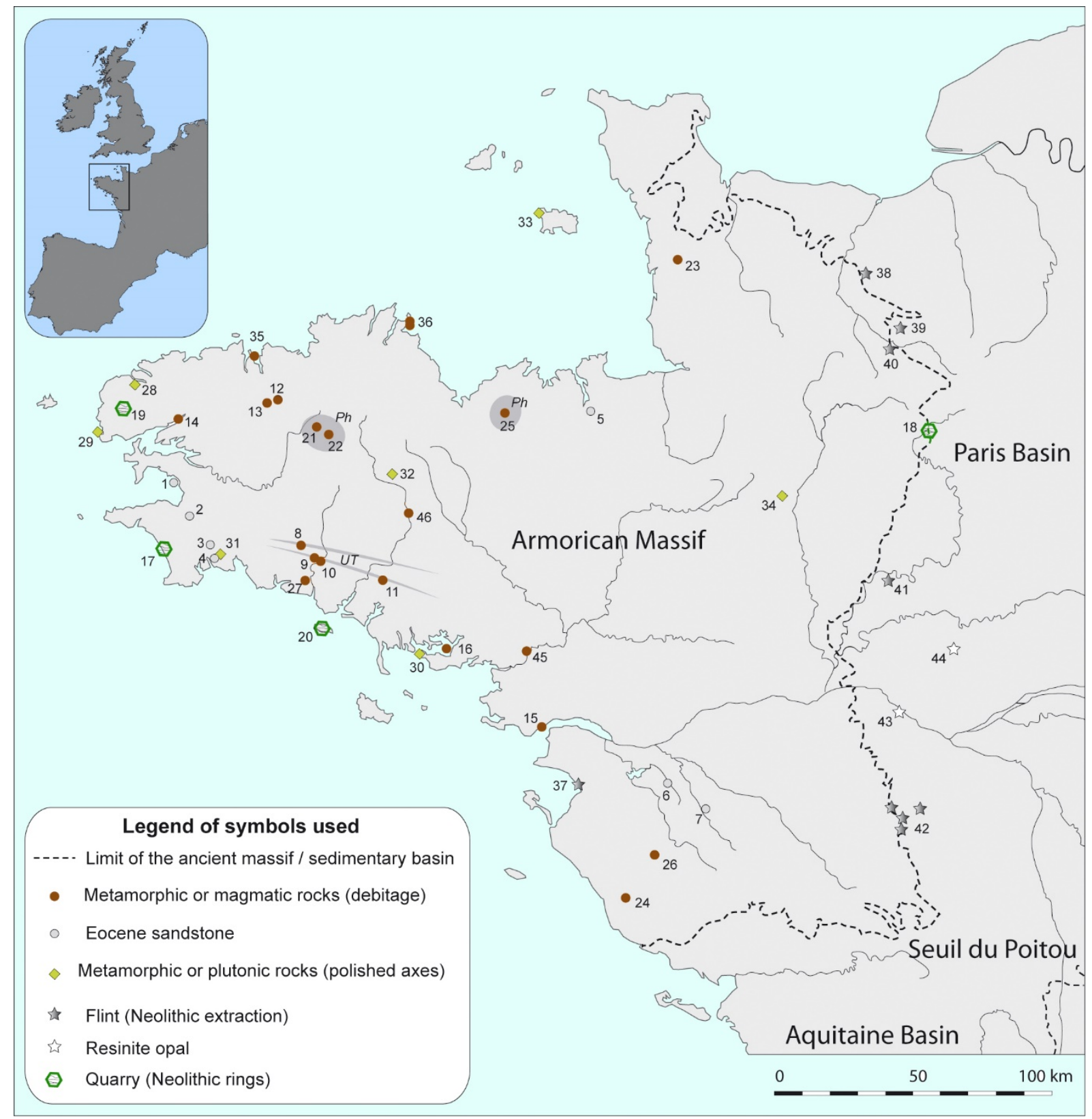

Figure 1. Identified primary sources of certain raw materials used for toolkits or for ornamental objects in the West of France, from the Lower Palaeolithic to the recent Neolithic. The most commonly used descriptive site names (locality, commune or 'land') by archaeologists are those used here:

- Eocene sandstones and quartzites (1: Bay of Douarnenez, 2: Kervouster, 3: le Moulin-du-Pont; 4: Kercou; 5: le Bois du-Rocher; 6: Montbert; 7: Les Essarts)

- Ultramylonites and cataclasites (8: Creac’h Mine Bihan and Kerboudou; 9: Loc-Ivy; 10: la Villeneuve; 11: Keriou-Saint-Maur and Languidic; 12: Mikaël and le Cosquer)

- Diverse metamorphic rocks (13: chalcedony from le Clos; 14: microquartzite from Forest-Landerneau; 15)

- Jasper from Saint-Nazaire; 16: chalcedony from l'Île-d’Ars; 45: chalcedony from Marzan; 46: chalcedony from Coët-Stival)

- Metamorphic rocks intended for making rings (17: chloritite from Ty-Lan; 18: spotted schist from Pissot; 19 : Lannuel; 20: île de Groix?)

- Siliceous shales (21: Chapelle-Rudunos; 22: Kerhuellan; 23: Coutances; 24: la Sauzinière; 25: Lamballe)

- Silcretes (26: la Merlière; 27: Kerchilven)

- Fibrolites (28: Plouguin; 29: Le Conquet; 30: Port-Navalo)

- Magmatic and metamorphic rocks (31: meta-hornblendite from Pleuven; 32: type A metadolerite from Plussulien; 33: dolerite from Jersey; 34: dolerite from Saint-Germain-le Guillaume; 35: vein quartz from Roc'h Gored; 36: Microgranite, tufas and dolerite from Ploubazlanec)

- Flint (37: les Moutiers-en-Retz; 38: Cinglais; 39: Rî-Ronais; 40: Rânes; 41: Vion; 42: Thouarsais) 
- Resinite opal (43 and 44).

(CAD: Grégor Marchand - Sources: Blanchard \& Forré 2003; Marchand 1999; Pailler 2007: 30; Tsobgou Ahoupe 2007: 280; Yven 2004; lithotheque PETRA - UMR 6566).

The Mesolithic industries known today in the Armorican Massif no longer bear any traces of the chalky cortex characteristic of the limestone bars from which they derive. Pebbles with eroded cortex were only gathered on beaches or in coastal bars. Recent palaeontological analyses showed that they were supplied by currently submerged Cretaceous levels (study in progress of Q. Aubel). These coastal pebbles are not evenly distributed on the beaches that extend over hundreds of kilometres of coastline; they are particularly abundant in the immense Bay of Audierne to the southwest of Brittany, which must have been a fundamental focal point for these economies (bay in front of $n^{\circ} 17$ in Figure 1). Considering the importance of flint pebbles, a study of their extraction zone was initiated in 2019 (led by: G. Marchand, N. Naudinot, M. Guiavarch \& G. Querré). Through the determination of the micropalaeonotological contents of these pebbles, it is sometimes possible to estimate the geological age of the initial formations, then in the perspective of the "chaine évolutive du silex", "evolutionary chain of flint" method developed by P. Fernandes and applied to Middle Palaeolithic studies (Fernandes \& Raynal 2006), then by V. Delvigne to Upper Palaeolithic case studies (Delvigne 2016: 49; Delvigne et al. 2017). This approach incorporates mineralogical, petrographic and microstructural variables on semi-quantitative bases and aims to reconstruct the different stages of transformation of a flint nodule from its sedimentary matrix until its discovery in an archaeological layer in the form of a tool or a waste product. Marine or fluvial beaches are also considered as raw material outcrops, with real possibilities of yielding identifiable signatures, which enables us to incorporate the main sources of knappable materials in our reflections on Prehistory in Brittany.

This collective research effort led to the identification or several dozen source deposits of knapped raw materials (Table 1; Figure 1). Plutonic rocks (dolerite, hornblendite, fibrolite), as well as metamorphic rocks (cataclasite, ultramylonite, microquartzite) or sedimentary rocks (schist, siliceous shale, Eocene sandstones, Armorican sandstone from the Primary era, chalcedony), very often correspond to particular cases or geological accidents, which produced rocks with specific properties, well identified during Prehistory. Metamorphic materials develop along the main Hercynian movements. This facilitates present-day identification, as it is possible for prospections to follow the faults already mapped by geologists. We obviously do not know if prehistoric prospectors had the same perception of this natural linear layout.

There are still a lot of blind spots in our knowledge of these rocks. Silcretes - continental silicifications of Tertiary age (Delvigne 2016: 55) - still form a set of very poorly localized rocks for which no general overview is available. They were identified in the carbonated substrata of the Seuil du Poitou in the Azilian of Chaloignes (Marchand et al. 2009) and in granitic formations in the Middle Palaeolithic of Kerquilven in Clohars-Carnoët (author's recent discovery). For the moment, they appear sporadically and we cannot go beyond the simplified image of a windfall effect for prehistoric knappers. Hornfels, very resistant rocks derived from contact metamorphism, also often appear as axes or hammerstones in the technical records of the Mesolithic and Neolithic; but their origins have not yet been clarified. 
Table 1. Main rock deposits used during the Mesolithic and Neolithic detected on the geological formations of the Armorican Massif, with indications of known exploitation modes. The last column mentions the main expected productions.

\begin{tabular}{|c|c|c|c|c|}
\hline Type of rock & Site & $\begin{array}{c}\text { Period of } \\
\text { exploitation }\end{array}$ & Extraction & $\begin{array}{c}\text { Main } \\
\text { productions }\end{array}$ \\
\hline $\begin{array}{l}\text { Flint (coastal } \\
\text { pebbles) }\end{array}$ & $\begin{array}{l}\text { Bay of Audierne } \\
\text { (Finistère) }\end{array}$ & $\begin{array}{l}\text { palaeolithic, } \\
\text { mesolithic, } \\
\text { neolithic }\end{array}$ & beaches & $\begin{array}{c}\text { blade- } \\
\text { bladelet-flake }\end{array}$ \\
\hline Eocene sandstones & $\begin{array}{c}\text { Bois-du-Rocher (La } \\
\text { Vicomté-sur-Rance, lle- } \\
\text { et-Vilaine) } \\
\text { Kervouster (Guengat, } \\
\text { Finistère) } \\
\text { Le Moulin-du-Pont } \\
\text { (Pleuven, Finistère) }\end{array}$ & $\begin{array}{l}\text { palaeolithic, } \\
\text { mesolithic, } \\
\text { neolithic }\end{array}$ & $\begin{array}{l}\text { rock slabs at } \\
\text { ground level }\end{array}$ & $\begin{array}{c}\text { blade- } \\
\text { bladelet-flake }\end{array}$ \\
\hline Ultramylonite & $\begin{array}{l}\text { Loc-Ivy (Tréméven, } \\
\text { Finistère) } \\
\text { Creac'h Miné Vihan } \\
\text { (Saint-Thurien, Finistère) } \\
\text { Keriou-Saint-Maur } \\
\text { (Languidic, Morbihan) }\end{array}$ & mesolithic & $\begin{array}{c}\text { unknown } \\
\text { (quarry or pit) }\end{array}$ & bladelet-flake \\
\hline Cataclasite & $\begin{array}{l}\text { Mikaël (Plougonven, } \\
\text { Finistère) }\end{array}$ & mesolithic & $\begin{array}{c}\text { unknown } \\
\text { (quarry or pit) }\end{array}$ & blade-flake \\
\hline Siliceous shale & $\begin{array}{c}\text { Kerhuellan (Plusquellec, } \\
\text { Côtes d'Armor) }\end{array}$ & mesolithic & $\begin{array}{l}\text { unknown } \\
\text { (quarry or pit) }\end{array}$ & bladelet-flake \\
\hline Microquartzite & $\begin{array}{c}\text { Le Crann (Forest- } \\
\text { Landerneau, Finistère) }\end{array}$ & mesolithic & rock quarry & blade-flake \\
\hline Chalcedony & $\begin{array}{l}\text { Le Clos (Plourin-lès- } \\
\text { Morlaix, Finistère) }\end{array}$ & mesolithic & $\begin{array}{l}\text { rock slabs at } \\
\text { ground level }\end{array}$ & Flake \\
\hline $\begin{array}{l}\text { Type-A } \\
\text { Metadolerite }\end{array}$ & $\begin{array}{c}\text { Quelfénec (Plussulien, } \\
\text { Côtes d'Armor) }\end{array}$ & neolithic & rock quarry & Axe \\
\hline Dolerite & $\begin{array}{l}\text { Beulin (Saint-Germain- } \\
\text { le-Guillaume, Mayenne) }\end{array}$ & neolithic & rock quarry & Axe \\
\hline Fibrolite & $\begin{array}{l}\text { Lannoulouarn (Plouguin, } \\
\text { Finistère) } \\
\text { Kermorvan (Le Conquet, } \\
\text { Finistère) }\end{array}$ & neolithic & $\begin{array}{l}\text { only colluvial } \\
\text { context? }\end{array}$ & Axe \\
\hline Metahornblendite & $\begin{array}{l}\text { Kerlevot (Pleuven, } \\
\text { Finistère) }\end{array}$ & neolithic & unknown & Axe \\
\hline Pissot Schist & $\begin{array}{l}\text { L'Ermitage (Saint- } \\
\text { Germain-du-Corbéis, } \\
\text { Orne) }\end{array}$ & neolithic & rock quarry & Ring \\
\hline Chloritite & $\begin{array}{l}\text { Lanvréon (Peumerit, } \\
\text { Finistère) }\end{array}$ & neolithic & surface & Ring \\
\hline
\end{tabular}

\subsection{Structures of rock exploitation}

On this ancient massif, the paucity of fine-grained knappable siliceous rocks for humans during Prehistory is thus compensated by increased sourcing possibilities for prehistorians. The most reliable prospection method consists in ascending the valleys that cut through natural outcrops, in particular the three main fault networks running along an east-west axis of 
the Armorican Massif, taking advantage of the exposed rocks and the sorting of rocky debris by water courses.

This first reconnaissance does not solve all the problems raised by the utilization of these local rocks, in particular the formal identification of extraction pits or cutting fronts in cliffs. When hundreds of rock fragments are present and when we observe dispersion over several sites and dozens of $\mathrm{km}^{2}$, we must rule out the hypothesis of opportunistic collection or accidental encounters and envisage long-term exploitations included in mobility circuits. Outcrops are rare, but their utilization is characterized by thousands of flakes when we finally detect them after hours of stalking. For the Mesolithic, an extraction pit at the foot of a small cliff was identified in the locality of le Crann (La Forest-Landerneau, Finistère) for the extraction of blocks of microquartzite roughed out in situ (Giot et al. 1977; Yven 2004: 285). A bed of charcoal provided a date from the middle of the seventh millennium BCE, making this site one of the rare "quarries" known for this period in France. The use of fire in the fragmentation process of the outcrop is noteworthy, as is the excavation of a pit, as both of these technical actions were more widely developed during the Neolithic. For the Middle and Recent Neolithic, fragmentation by fire was also used for the extraction of type-A metadolerite in a vast quarry excavated in the 1960s and 1970s (Le Roux 1999: 38). But generally speaking, rock extraction conditions in the Armorican Massif during the Mesolithic remain mysterious, as do the techniques developed. The modest traces left in the landscape and their destruction during subsequent exploitations are often the cause of this lack of knowledge, but archaeologists also appear to have been partly negligent, as they were often preoccupied by more prestigious pursuits. In any event, it would be fitting in the future to direct research towards these exploitation sites, through targeted archaeological excavations.

\subsection{The archaeological corpuses}

Systematic prospections carried out during the 1990s and 2000s in the Finistère department, in the west of the Breton peninsula, gave rise to a database of 1,400 sites (Gouletquer et al. 1996; Marchand 2005; 2009: 507-508). The study of 700 of these surface assemblages (96,391 pieces) showed that 200 sites can be described as Mesolithic (39\% Early Mesolithic, 38\% Final Mesolithic, 23\% Undetermined Mesolithic). Thirteen sites have been excavated in this department, enhancing our knowledge of the proportions of lithic pieces. In the whole of Brittany, about fifty sites have been excavated. This database is now propitious to the characterization of transfers of materials.

\subsection{Geological and mechanical analyses}

The identification of the rocks from a geological viewpoint was combined with a definition of their mechanical reactions to knapping, in collaboration with the Larmaur (Laboratory of Applied Mechanical Research) of the University of Rennes 1 . The project focused on the Middle Palaeolithic (Huet 2006: 75) and the Mesolithic (Tsobgou Ahoupe 2006, 2007: 45, 2010). The following characteristics in particular were measured: tenacity (resistance to fracturing), hardness (resistance to the penetration of force from the impactor), elasticity (the speed at which the material returns to its initial state after the impact), isotropy (continuity of the materials) and compressibility. When we correlate these measurements to production types (Table 2), we observe that the rocks used in laminar or bladelet projects, which were extremely widespread during the European Mesolithic as a cultural norm (Marchand \& Perrin 2017) present relatively low tenacity and average hardness: the microquartzite from Forest-Landerneau is similar in this respect to the Eocene sandstone (also known as "lustrous sandstone") and flint pebbles. 
The mineralogical nature of sedimentary rocks is more stable than for metamorphic rocks. Cataclasites are too resistant to obtain bladelets, but sometimes large thick blades are detached with a hammerstone. The ultramylonites from the south of Brittany are also too variable, unpredictable and contain too many fault lines to be used for the production of elongated products.

Table 2. Classification of rocks from the Armorican Massif used in the Mesolithic period. Tenacity = resistance to fracturing (propagation of cracks); Hardness = resistance to the penetration of force from the impactor; Elasticity = the speed at which the material returns to its initial state after the impact (adapted from Marchand \& Tsobgou Ahoupe 2009).

\begin{tabular}{|c|c|c|c|c|c|c|c|}
\hline Rocks & Hardness & Elasticity & Tenacity & 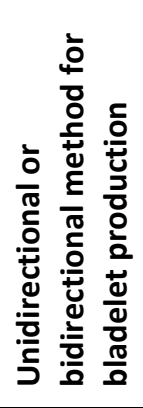 & 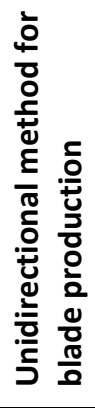 & 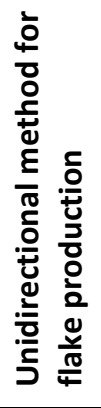 & 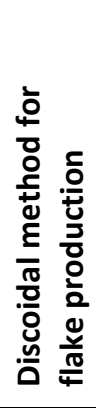 \\
\hline Flint (coastal pebbles) & medium & low & $\begin{array}{l}\text { low or } \\
\text { medium }\end{array}$ & +++ & +++ & +++ & +++ \\
\hline Eocene sandstones & medium & $\begin{array}{c}\text { high } \\
\text { variability }\end{array}$ & $\begin{array}{l}\text { low or } \\
\text { medium }\end{array}$ & +++ & +++ & +++ & +++ \\
\hline Mikaël cataclasite & Low & high & high & & + & +++ & +++ \\
\hline Tréméven & high & high & high & & & +++ & +++ \\
\hline Ultramylonite & variability & variability & variability & & & & \\
\hline Callac Siliceous shale & Low & low & low & + & & +++ & +++ \\
\hline Clos chalcedony & no data & no data & no data & + & & +++ & +++ \\
\hline $\begin{array}{l}\text { Forest-Landerneau } \\
\text { Microquartzite }\end{array}$ & medium & low & $\begin{array}{l}\text { low or } \\
\text { medium }\end{array}$ & + & + & +++ & +++ \\
\hline
\end{tabular}

Local rocks were the most abundantly used during the Middle Palaeolithic and the Mesolithic periods, which has yet to be explained. In an overall context where good quality materials for knapping were rare, we observe divergent choices between these two periods. Tenacious large-grained rocks, such as dolerites, keratophyric tufas, or minerals with large crystals such as quartz, were well adapted to making massive Palaeolithic tools, provided that they were sufficiently large. Conversely, they were not used for Mesolithic industries at all, whereas fine-grained metamorphic rocks such as ultramylonites or cataclasites were widely utilised. Large rocks were sometimes available but in reality, the numerous cleavage planes only leave rather small modules for debitage. The mechanical characters of the rocks thus partly account for the success (or not) of the rocks, but their management depends on economic, cultural and geopolitical criteria, which we are now going to examine.

\section{Integration of the different rocks in Mesolithic technical systems: A decision-making process}

\subsection{Revealing the geological potential}

Geological formations predate human societies and are of variable value for making technical objects depending on human needs and cultural standards. Here, geological potential refers to the capacity to respond to the demands of technical systems, or in other words, the 
expression of a more or less immediate or more or less anticipated need. Above, we took a glance at the "physical" characters of these different rocks, but their adoption, use and dispersion depend on how they are accepted by human groups. This process is closely dependent on the cultural standards of the group (habitus), that is, the mental image of a collectively “acceptable” tool (Figure 2).

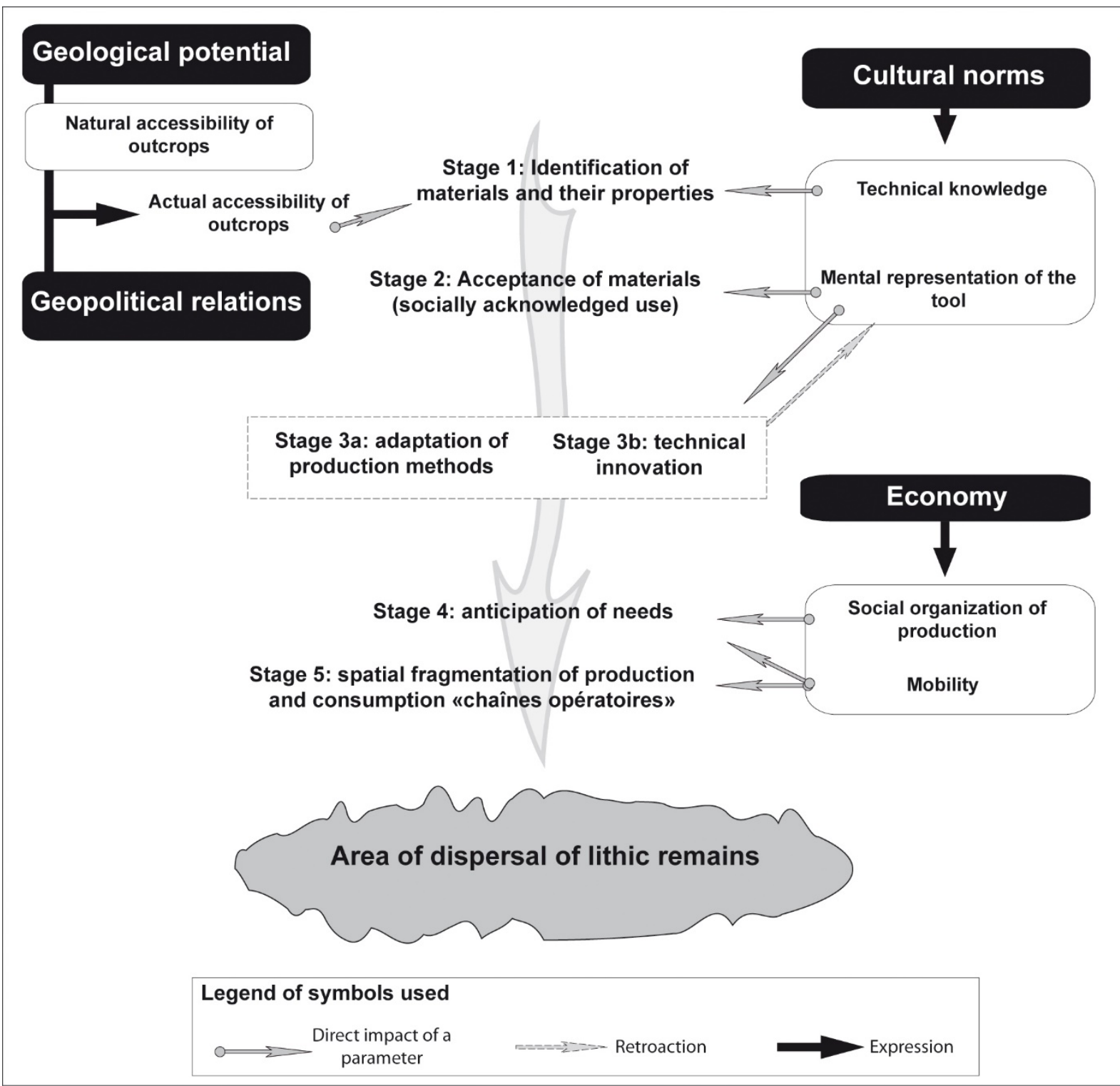

Figure 2. Process of integration of a local rock in a technical system and parameters influencing spatial transfer patterns. Geological potential, intergroup relations, cultural norms and the organization of the economy can only influence the acceptance of rocks through certain parameters. Thus, for the Final Mesolithic, individual and collective technical knowledge allows the development or not of norms (the knapper knows by experience or transmission whether or not one will be able to obtain blades or trapezes acceptable to the cultural standards).

The rock is only socialized and accepted on three conditions:

- an identification of its value and adaptability to the technical project, which implies a certain level of geographic and mechanical knowledge, but also adaptation to cultural standards and a certain appreciation of the rock; otherwise it would not be taken into consideration, 
- $\quad$ an effective visibility of the rocks, which can be dissimulated by vegetation or natural sedimentary deposits, an accessibility verified by adapted prospections, contacts and exchanges, by chance during hunting or again as a result of traditions,

- $\quad$ an authorization to access the deposit, when the latter is controlled by another group, a parameter that depends on broader geopolitical relations; this access can be direct or indirect, in the form of exchanges which involve possible terms of compensation.

A crucial technical stage then intervenes in this process of integration of rocks, which has major consequences for prehistorians' perception of artefacts. In order to adapt to the mechanical characteristics of materials, Mesolithic knappers must often modify their flaking methods or techniques (Figure 2, stage 3). This necessity for adaptation can thus be a source of innovation, either in the knapping process, or in tool design. The most eloquent example of this comes from the Late Mesolithic (Teviecian; 6200-5300 BCE). Given the rather homogeneous structure of the Mikaël cataclasites and the huge volume of these blocks, it is possible to knap thick blades, on condition that great force is applied, as cataclasites are among the toughest rocks. As a result, we observe a very original production of wide blades with a rectilinear profile on these sites. For this, a hammerstone is applied to open, or nearly orthogonal knapping angles, with marked abrasion of the overhang. Methods are still poorly known apart from the fact that only one striking platform was used. These large and thick blades are used for their cutting edges, but they do not replace flint supports, they are an addition to the available tools. Functional analyses could refine this question and help us to better understand this original technical dynamic.

Other metamorphic rocks, such as ultramylonites from Tréméven or chalcedonies from le Clos present marked lamination. For them, bifacial discoid debitage was applied between the cleavage planes of the rock. In this way, for the chalcedony from le Clos, production must be limited to areas with thicknesses of about $20 \mathrm{~mm}$. The orthogonal flaking of these planes entails a high risk of breakage, as the shock wave is rapidly stopped by sequences of beds of different composition. Short and thin flakes, with convergent edges, are thus a major aim of these productions, to the detriment of blades. These flakes were used as blanks for arrowheads. We thus observe that the widespread Late Mesolithic aim in Western Europe of producing bladelets for arrowheads and notched blades (Allard 2017; Clark 1958; Marchand, 1999; 2014; Marchand \& Perrin 2017) is abandoned. As a rule, the technical changes observed during the whole Armorican Mesolithic are a decrease in the dimensions of all the flaked products, even in flint, a reduced proportion of blades and bladelets and a low degree of product regularity. It is obvious, however, that certain technical standards remain, notably those of the arrow elements, whether the triangles of the Early Mesolithic or the trapezes of the Late Mesolithic. This designates these tools of hunting or warfare as objects whose configuration seems non-negotiable, whatever the geological potential or other settings.

At this stage, we can thus distinguish several methods for the incorporation of local rocks into technical systems. Flint gathered on beaches in the form of coastal pebbles is still the main basis for productions during Prehistory in the West of France, but it seems necessary to differentiate three main categories of rocks depending on their position in the technical system:

- Complementary rocks are incorporated into the technical system for activities other than those for which flint is used. For the Mesolithic in the West of France, these include hammerstones, elongated pebbles and rare examples of picks.

- Substitution rocks compensate for the absence of flint and are used for the same functions, with or without an adaptation of debitage methods. For the Mesolithic in the West of France, this category consists of a very wide array of sedimentary, metamorphic and plutonic rocks described in this article. 
- Socially valued rocks designate goods - and by extension here, the exceptional or unexceptional materials used to make them - found in particular in funerary contexts or in ritual hoards; in the region they are found above all during the Neolithic.

The spatial dispersion of worked rocks thus depends on economic and social parameters (Figure 2, stages 4 and 5). Again, they can be expressed through several filters, namely the social organization of production and mobility practices. In order to understand the distribution ranges of the rocks of interest here, we must consider the central notion of the anticipation of needs.

\section{Better defining needs: examples of differentiated management of lithic materials in coastal and continental areas}

\subsection{Beg-er-Vil at Quiberon: an example of a coastal economy based on flint}

The Mesolithic dwelling of Beg-er-Vil at Quiberon (Morbihan) consists of a remarkably well-preserved shell level, visible in a palaeo-cliff. It was excavated by O. Kayser from 1985 to 1988, then from 2012 to 2018 by G. Marchand and C. Dupont (Marchand et al. 2018). The site was explored by an in-depth excavation over a surface of more than $180 \mathrm{~m}^{2}$ (for a total surface of $600 \mathrm{~m}^{2}$ ), and is now considered as a reference site in Europe for understanding societies during the last two centuries of the seventh millennium BCE, in particular for assessing coastal zone activities. Excavations focused on the shell level and its sandy border. They revealed exclusively domestic structures, such as different types of hearths, including many pit hearths, and the post wedges of two circular dwelling structures. Results from lithic studies are still only partially available, but our observations already concern 5,884 objects gathered between 1985 and 1988 and 25,000 of the lithic objects collected from 2012 to 2018.

The vast majority of the recorded objects are in flint (81.8\%), but flakes from pebbles in other rocks, such as quartz (11\%), quartzite (2\%), quartzite-sandstone (2\%) are also present. Sandstone, schists and granites are rarer (less than $0.1 \%$ each). These flakes and fragments result from the manufacture of macro tools, but also sometimes from very simple debitage with little predetermination, geared towards the production of robust cutting edges. The flint is generally of very poor quality, very faulted, with numerous calcareous or siliceous inclusions. It comes from coastal pebbles available at considerable distances from the dwelling. In fact, the Pleistocene beach on which the site is installed and which is exposed in a cliff section is a good indicator of local geological availability: it contains no flint pebbles and only very marginal proportions of these pebbles are found on the present-day beach. Was acquisition possible just beside the dwelling? Our investigation is somewhat limited by the drastic changes to the coastal landscape over the past 8,000 years. However, we can underline the abundance of this resource on the west coasts of Téviec Island, $10 \mathrm{~km}$ from Beg-er-Vil, as the crow flies, or again on the southern coastline of the island of Houat, $13 \mathrm{~km}$ away. Nonetheless, these distances are high for such a predominant raw material and we can logically envisage the existence of coastal bars of flint pebbles near the site, especially as the abundance of cortical flakes and crude waste do not show any signs of the spatial fragmentation of knapping, such as prior roughing out of pebbles or an importation of prepared blanks.

Therefore, huge technical constraints weighed on this debitage and these were offset by the flexibility of the methods used (Marchand, 1999: 145-161). The products obtained are short, apart from several rather large backed knives (more than $60 \mathrm{~mm}$ long), which perhaps conveys the 'price' to be paid. Lamellar production is rather limited and as a result, is very sought after for the toolkit: blades represent $4 \%$ of all products but $22 \%$ of blanks for tools; bladelets represent $8 \%$ of all products, but $13 \%$ of common tool blanks and $66 \%$ of arrowhead blanks (Figure 3). The production of these blades and bladelets involves indirect percussion 
for certain nodules with a homogeneous structure, but more generally, the use of hammerstone percussion. Production generally involves a single striking platform, most often with frontal retreat (and thus bladelets with a 2-1-2' rhythm, issued from the centre of the core volume, in dominant proportions). There is thus common volumetric management in the Late Mesolithic, at least in France, but with a certain slackening of standards and the more frequent use of the hammerstone (Figure 4).
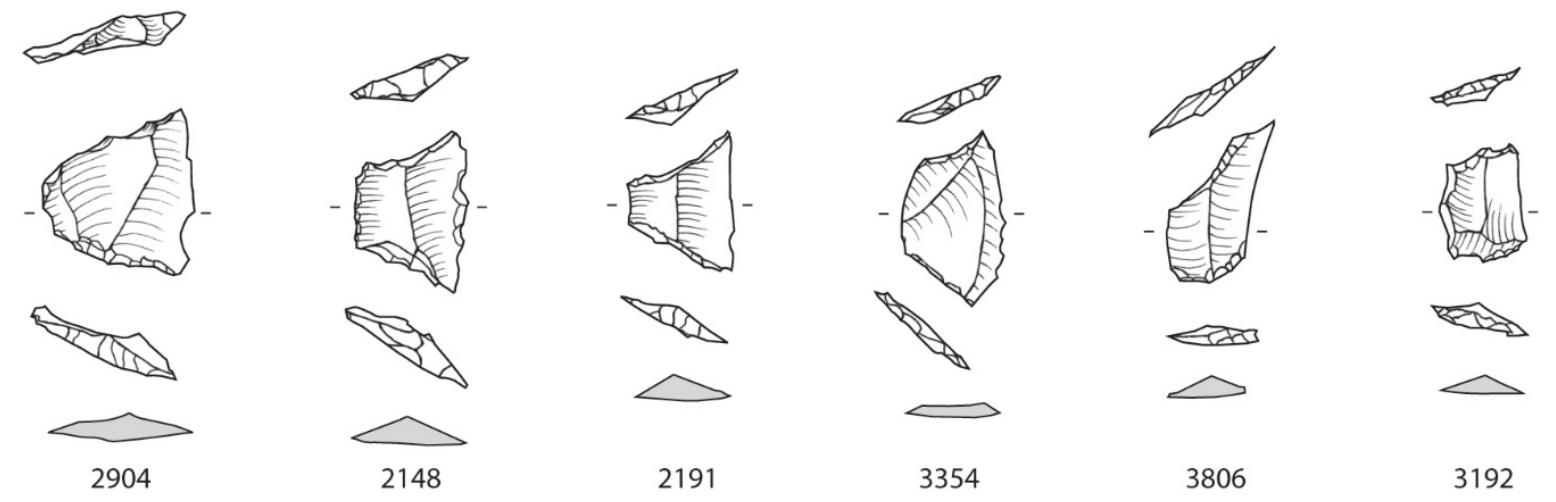

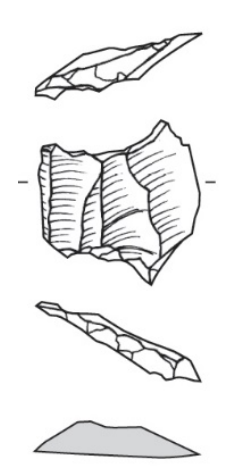

BB35-D, 5.1

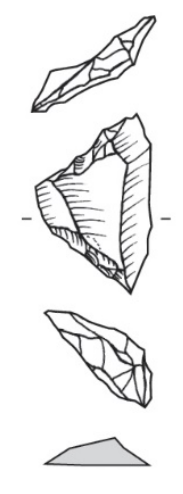

BH33-B, 5.4

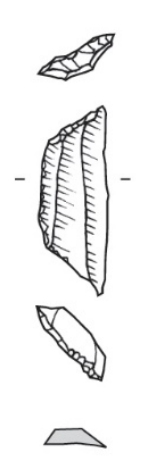

BH37-D, 4.1

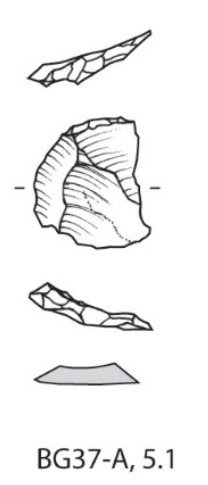

0

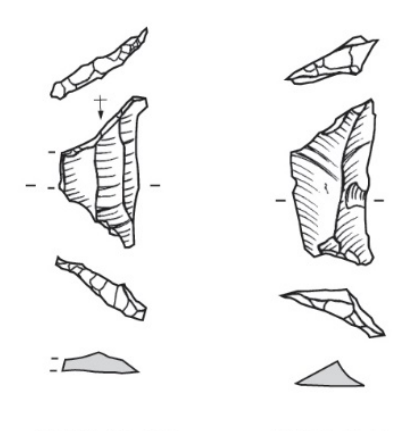

BH33-D, $5.2 \quad$ BF36-C, 5.4 $5 \mathrm{~cm}$

Figure 3. Functional analyses showed that the symmetrical trapezoids of the Late Mesolithic site of Beg-er-Vil were transverse arrows. They are preferentially made on bladelets but can be implanted on all types of noncortical blanks (Drawings Diana Nukushina, modified by Grégor Marchand).

The monotony of arrowhead types is a striking feature of the Beg-er-Vil assemblage, since as a rule, sites from this period are characterized by the variety of these artefacts. Generally speaking, these arrowheads are symmetric trapezoid bi-truncations (or symmetric trapezes), made by direct retouch with a hammerstone, with a cutting edge measuring between 10 and $15 \mathrm{~mm}$. The common toolkit is consistent with expectations, with a predominance of tools with a chipped blade (also referred to as a posteriori tools). Generally speaking, these flakes are not very calibrated and were used in a non-intensive way for their cutting edges without resharpening. Among the toolkit, we can mention backed knives, which are very characteristic of this Beg-er-Vil facies of the Teviecian. There are also truncations on all types of blanks. End scrapers are not very frequent and not very elaborate, with a slightly developed and not very re-sharpened arc. Notches and denticulates represent a third of these transformed tools, but like for the end scrapers, retouch is neither intensive nor wide-ranging.

The number of ground stone tools is rather low alongside these tens of thousands of flaked remains (Marchand et al. 2019). We counted 130 unquestionable specimens of these tools with macroscopic traces (use-wear or retouches) and 23 hypothetical tools that require 
more in-depth analyses to determine whether or not they bear traces of use. Nine functional types have been distinguished, with predominant hammerstones (64\%), clearly used for the debitage of mineral materials, but also perhaps for breaking hard animal matter. These are followed by pebbles used as intermediary elements, hit very hard along a longitudinal axis (8\%), and pebble tools comprising a single pick (13\%). Following our nomenclature, the rocks used are complementary rocks; quartz $(42 \%)$, sandstone $(18 \%)$, granite $(12 \%)$ or quartzite-sandstone (8\%).

All of the flaked rocks and hammerstones come from the foreshore near the site, with no influx of native rocks. This observation is also applicable to all the other Mesolithic sites studied on the coasts of Southern Brittany. The pebbles used at Beg-er-Vil are faulted and often frost-cracked and were not conducive to the widespread development of indirect percussion for bladelet production, as was the case elsewhere in France.
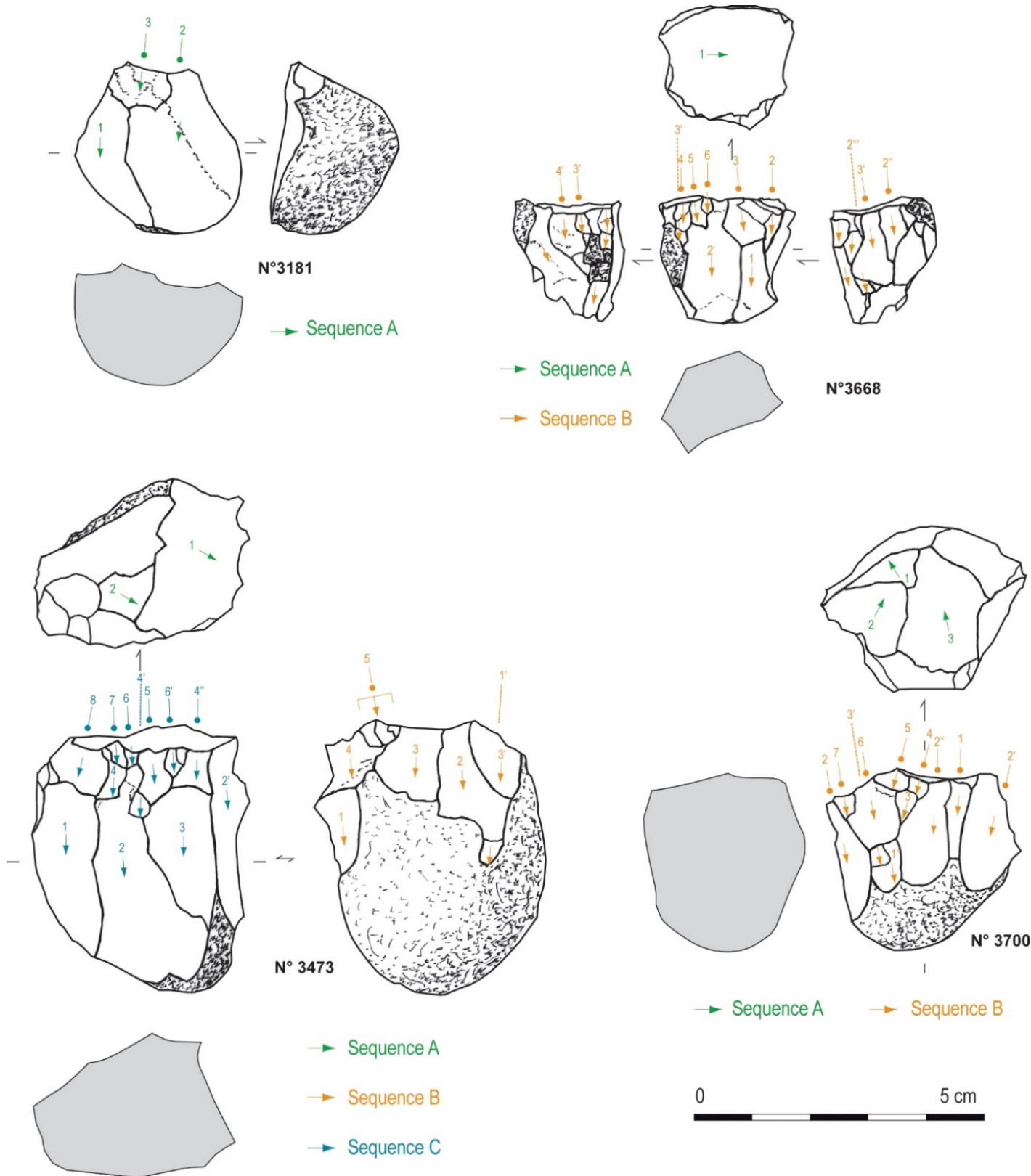

Figure 4. Core with preferential unipolar exploitation, in successive sequences, exploiting small flint pebbles of very poor quality collected on the beaches. The technique of percussion is most often done with a hammerstone (Analysis and drawings: Diana Nukushina). 


\subsection{La Presqu'île of Brennilis: example of a continental economy}

The site of la Presqu'île is currently in the middle of the lake formed by the Brennilis dam but was located on the northern slope of a small watercourse during the Mesolithic, about fifty kilometres from present-day coasts (Marchand 2005) (Figure 5). It was discovered in 1989 and was immediately acknowledged as a major Mesolithic site in Central Brittany, on account of its abundant lithic assemblage and its chronological coherence (Gouletquer et al. 1996). The 16 test pits made over a surface of $47 \mathrm{~m}^{2}$ in 2001 showed that the site was totally reworked as a result of the construction of the dam lake in the 1930s, which dispersed thousands of knapped stones over the valley slope. No archaeological levels and $a$ fortiori no structures were unearthed. Nevertheless, this site with particularly abundant remains is still the most complete and technically speaking, the most homogeneous example of a Late Mesolithic site from the interior of the Armorican peninsula.

The 2,483 lithic objects gathered at the site comprise the same tool types as at Beg-erVil, with a prevalence of symmetric trapezes among the arrowheads and very few common standardized tools (truncated blades, end scrapers on flakes and denticulated flakes). However, the wide variety of raw materials contrasts sharply with the observations made at the coastal site (Table 3). Flint is predominant (50-60\%); substitution rocks are plentiful, as well as Eocene sandstones, microquartzites from Forest-Landerneau, Mikaël ultramylonites (5-10 \%). The marginal rocks are siliceous shales, chalcedonies from le Clos and Armorican sandstones (less than $5 \%$ ). These three categories seem to be normal for a Mesolithic lamellar project, as only the rolled flint pebbles are apt for the recurrent production of narrow elements with fine cutting edges, whereas the substitution rocks were used for other tool blanks (thick blades or flakes), accessible with new methods. All the rocks were brought to the site as nontransformed blocks and not as finished products. But why import mediocre rocks such as siliceous shales from Callac? The transport of these materials does not correspond to a strict technical logic that would see long-distance transport only for the good raw materials. It could rather be the indirect proof of the vitality of Mesolithic economies in these areas or a site of cyclical aggregation of several populations: people move with their current production and these mediocre rocks inform us both about the extent of displacement and about distant debitage practices. Other hypotheses can be raised here, such as the importation of poor quality rocks devolved only to young knappers (or apprentices) or a symbolic attribute of certain rocks. In the first case, homogenous lithic assemblages collected in excavations will be needed to make a cut, while discoveries in burials or caches could shed light on these statuses of the different Armorican rocks.

It is interesting to refine the analysis by examining the proportions themselves and by exploring what they mean in terms of Mesolithic human values. The representation of materials at la Presqu'île of Brennilis does not correspond to the rule of distance-related decrease, which was widespread at that time, whereby the nearest materials are the most abundant:

- the nearest sources of flint pebbles are the Bay of Morlaix to the north or the Bay of Douarnenez to the southwest (35 km),

- the Eocene sandstone from the region of Douarnenez (Kervouster) is known in an outcrop nearly 35 kilometres southeast of Brennilis but it is very possible that other deposits will be identified in the future, so this provenance must be considered to be provisional,

- $\quad$ the microquartzite from la Forest-Landerneau is a Brioverian quartzite, derived from a strong metamorphism of sandstone bars in the well-known zone of tectonic accidents in the valley of Elorn, $31 \mathrm{~km}$ northwest of the Presqu'île, 
- the Mikaël ultramylonite is known at the outcrop of Plougonven, $20 \mathrm{~km}$ north of the site, in the north Armorican shear plane,

- an outcrop of le Clos chalcedony is known in the locality of Le Clos (Plourin-lèsMorlaix), in this same fault zone (16 km to the north),

- siliceous shale is now well known in an archaeological context in the region of Callac, $32 \mathrm{~km}$ east of the Presqu'île, and from a geological perspective, this represents the most plausible provenance zone for this rock,

- Armorican sandstone and quartz are the only genuinely local rocks. The nearest sandstone outcrops are on the eastern, northern and southern borders of Yeun-Ellez, at about two kilometres from the site, whereas quartz veins run through the schist substratum.

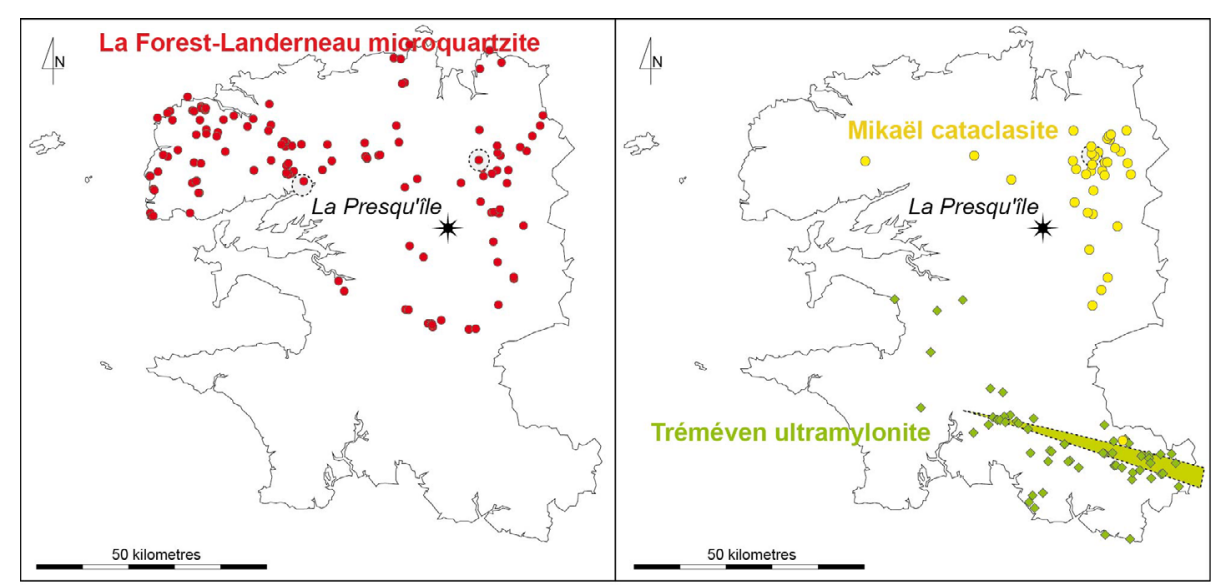

A : diffusion of three local raw materials in Finistère (all periods)

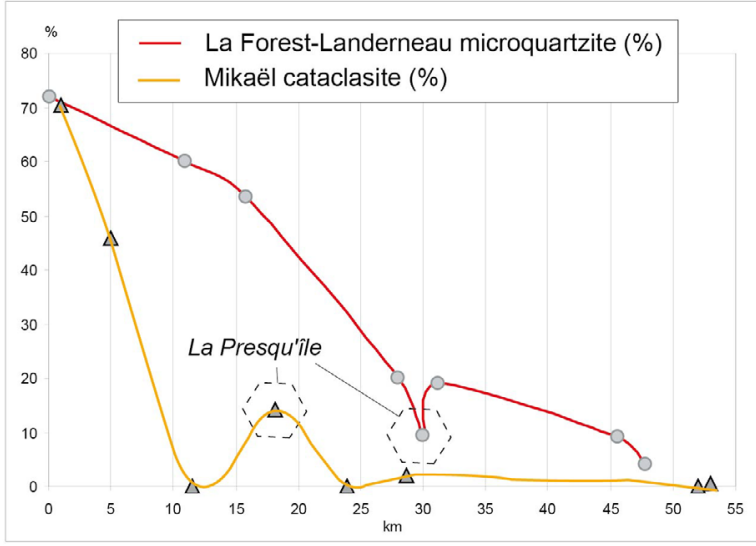

B : Diffusion rates of two raw material in Northern Finistère during the sixth millenium BCE : the irregularities at La Presqu'ile (Brennilis, Finistère) are they due to a particular status of the site or to an effect of circumstances at the end of the networks?
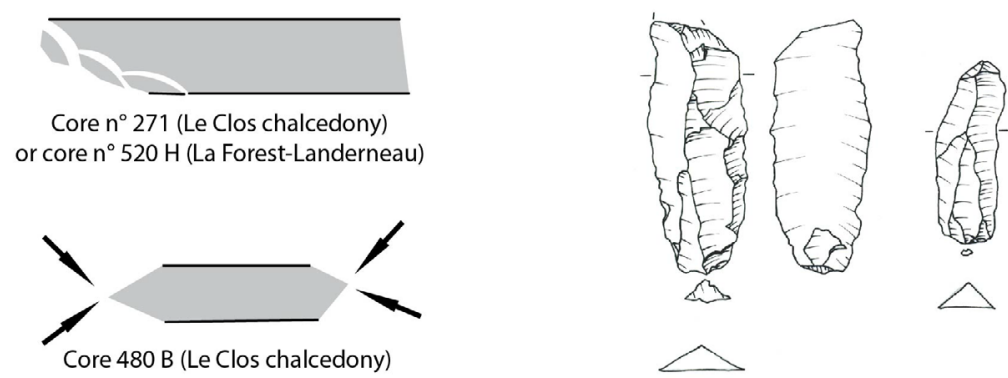

Mikaël cataclasite : A blade production on this tenacious rock, with easily damaged cutting-edge.

C: At La Presqu'île, adaptation of the reduction process to the raw material structures

Figure 5. Spatial distribution of autochthonous lithic raw materials in the department of Finistère (west of Brittany) during the 6th millenium BCE (CAD: Grégor Marchand). 
The production methods corresponding to this wide variety of rocks are also very diversified. The lamellar objective is clear for flint pebbles. The core flaking surface is implanted on a wide face and exploitation sometimes extends to the sides. When they are abandoned, the knapped surfaces of the flint cores measure on average $29 \mathrm{~mm}$ long and 31 $\mathrm{mm}$ wide; the last removals measure $24 \mathrm{~mm}$ by $18 \mathrm{~mm}$. The cores in Mikaël ultramylonite are much larger, measuring $50 \mathrm{~mm}$ as opposed to $38 \mathrm{~mm}$ for flint. The knapped core surfaces are also larger (37 x $42 \mathrm{~mm}$ ). This resistant rock is not conducive to large bladelet debitage and yet its MNI is by no means insignificant (31 \%). However, this rate was calculated exclusively for whole and proximal blanks and it is probable that it also includes a number of thin flakes and laminar flakes. On the other hand, we observe massive blades in this material, with a rectilinear profile, smooth butts, closed flaking angles and in-turned hard hammer percussion. These blades, in the same way as the flakes, are not standardized and it is difficult to grasp their method of extraction. For the Eocene sandstone, we distinguish the debitage of wide and very thin flakes with a multipolar method on one or two faces, probably linked to discoidal cores. The technique deployed is direct percussion with a hammerstone, with slight abrasion of the overhang. The possibility of small lamellar sequences can be considered, even with irregular products. The microquartzite from the Forest-Landerneau is also worked with multipolar or discoidal methods, with thin products with non-parallel ridges. There is also debitage of short bladelets or lamellar flakes, with two facets.

The transformation rate is variable depending on the rocks and we will use this rate here as a quantitative indicator of the importance of materials in the value system. It attains its peak value for flint, followed by microquartzite from Forest-Landerneau, then by Eocene sandstone (Table 3). It is much lower for rocks of mediocre quality, such as siliceous shale or quartz. Apart from the latter and for Armorican sandstone, we do not observe any exclusion of rock types related to tool types; in particular, arrowheads are made in flint, but also in siliceous shale or Mikaël ultramylonite. Whereas tools are similar at Beg-er-Vil and the Presqu'île, the management of local lithic resources radically changes technical procedures.

Table 3. La Presqu’̂̂le (Brennilis). Rivage, 2001. Main categories of lithic productions, proportions of raw materials and transformation rates. Abbreviations: fUM: ultramylonite from Mikaël; Ge: Eocene sandstone; FL: microquartzite from Forest-Landerneau; Qtz: quartz; Clos: Chalcedony from le Clos; GA: Armorican sandstone; Pht: phtanite or siliceous shale.

\begin{tabular}{lcccccccccc}
\hline & Flint & FL & UM & Ge & Qtz & Clos & GA & Pht & Divers & Total \\
\hline Non-transformed & 617 & 77 & 78 & 87 & 29 & 26 & 20 & 39 & 4 & 977 \\
Tools & 56 & 5 & 2 & 6 & 1 & 0 & 0 & 1 & 0 & 71 \\
Total & 673 & 82 & 80 & 93 & 30 & 26 & 20 & 40 & 4 & 1048 \\
\% raw materials & 64.2 & 7.8 & 7.6 & 8.9 & 2.9 & 2.5 & 1.9 & 3.8 & 0.4 & 100.0 \\
\% transformation & 8.3 & 6.1 & 2.5 & 6.5 & 3.3 & 0.0 & 0.0 & 2.5 & 0,0 & 6.8 \\
\hline
\end{tabular}

\section{Understanding the distribution areas of rocks}

\subsection{Overall dynamics of Mesolithic rock dispersions}

During the sixth millennium BCE, raw material acquisition territories are characterized by several parameters:

- $\quad$ Flint gathered on the foreshore in the form of rolled pebbles is the predominant raw material for lithic production (on average $77 \%$ of artefacts during the Late Mesolithic as opposed to 86\% during the Early Mesolithic), with a centripetal diffusion pattern from the peninsula towards the interior.

- $\quad$ The diffusion limit for rocks derived from the Armorican Massif ranges between 30 and $50 \mathrm{~km}$. 
- $\quad$ During field surveys, local rocks are very rarely discovered on the coast (generally located about twenty kilometres away, as a result of geological coincidences), which challenges the idea of complementarity between coastal and continental territories and a hypothetical nomadic group.

- $\quad$ No exchanges of local metamorphic rocks seem to have taken place between the south and the north of the peninsula.

The more or less important utilization of local rocks characterizes these continental Mesolithic economies, with an intensification from the eighth to the sixth millennia (Marchand 2009: 508-509). On the other hand, Mesolithic debitage on the coast relied almost exclusively on flint pebbles gathered on beaches, at least for the Late Mesolithic (the Early Mesolithic coastal dwellings were often submerged by the marine transgression). This observation suggests the hypothesis of the existence of two mobility systems for the exploitation of resources, at least at the end of the seventh and sixth millennia BCE, rather than imagining pendular movements from the continent towards the coast. In continental zones, more frequent movement rhythms would have entailed less investment in settlement structures. The activities carried out in small rock shelters, such as Kerbizien at Huelgoat or Pont-Glas at Plounéour-Ménez, would thus have played an important role in these circuits. Conversely, complex dwelling structures on the coast would denote long occupations or - $a$ minima - specific territorial approaches, where a site would be very privileged by a human community, for dwelling purposes and for burying its dead.

\subsection{Evolution of transfers and distribution areas}

We will assume that the quantity of available pebbles decreased over time, as the rise in sea levels distanced beaches from the calcareous bars which partly supplied them. Furthermore, based on current trends, the progressive stabilisation of the coastal limit after the seventh millennium prevented the renewal of offshore bars. The intense utilization of these resources progressively reduced the number of available nodules and probably their dimensions or quality. The increased use of siliceous rocks from the Armorican Massif would have compensated for this depletion (Marchand 2005; 2009: 509; Marchand \& Tsobgou Ahoupe 2009). Indeed, during the Early Mesolithic (Bertheaume group - end of the ninth millennium - beginning of the eighth millennium BCE), Eocene sandstones were the only major alternative to flint. These were supplemented by ultramylonites, cataclasites and siliceous shales during the Teviecian (sixth millennium).

The still conjectural explanation accounting for this shift towards poorer-quality rocks than flints in inland areas (but not on the coast) thus lies somewhere between environmental determinism and geopolitical choice.

It is not possible to rule out other causes specific to societies and the human choices carried out there, such as a possible demographic increase, leading to increased needs, restricted access due to specific geopolitical conditions or again, a change in mobility patterns with less frequent movements along the coast. In any case, flint always remained preponderant for the production of cutting tools during the Mesolithic and it represents at least $50 \%$ of assemblages, apart from in quarry-sites, to use the terminology of E. Yven (2003). Flint pebbles are dispersed in a centripetal pattern from beaches towards the interior of the peninsula, at a distance ranging between thirty and fifty kilometres from their sources. The magmatic, metamorphic or sedimentary rocks specific to the Armorican Massif were thus substitution rocks. Practically no exchanges of these materials seem to have taken place between the north and the south of the peninsula. In addition, hinterland rocks, generally of poorer quality than flint, are only rarely found on coastal sites, which does not point to an Earth-Sea complementarity in the economy of a same group. 
The overall mediocrity of the rocks adopted by Mesolithic humans forced archaeologists to think about the conditions underlying their insertion into technical systems. The success of a rock can be tangibly measured by two criteria: the quantities of rocks transferred and the distances travelled by them. Blades and bladelets are central to debitage aims during the Mesolithic in Western Europe. Yet, many Armorican rocks are too resistant or affected by too many faults and cleavage planes to produce these types of products. They were nonetheless used, by applying original methods such as discoidal debitage for metamorphic rocks with parallel cleavage planes, such as ultramylonites. The use of Mikaël cataclasites in the north of Finistère shows us another aspect of these economic choices: robust blades, produced by a hammerstone, could be and were produced. However, their diffusion radius is very low, and decreases significantly several kilometres away from the source and disappears altogether at distances of about twenty kilometres.

This context of geological paucity is ultimately fortunate for us, as it dynamizes all the prehistoric technical systems by revealing to us what was negotiable and what was not. For Mesolithic hunter-gatherers on the Armorican Massif, sacrificing technical standards seemed to be preferable to long-distance acquisitions by importation or exchanges. This seems to denote restricted interactions with neighbouring communities and contributes to characterizing these societies from the first half of the Holocene. Only the configuration of the weapons seems to escape these constraints. Obviously, their small dimensions impose the use of smaller volumes to be debited and they are always easier to collect in the environment. But we must not forget the need to produce them in large numbers with standard dimensions. The principle of composite tools is precisely to be able to repair them quickly. This could explain the appeal of regular lamellar supports, "against wind and tide". And this then has an impact on the methods used. The reduction in supply territories observed throughout the European Mesolithic does not mean a reduction in long-distance contacts: the wide dissemination of technical standards for Late Mesolithic demonstrates this. It is rather a refocusing of the role of lithic materials that we are witnessing, with an interpretation of technical and cultural norms adapted to intra- and inter-group organizations specific to these Holocene groups.

\section{References}

Allard, P. 2017, Variability of laminar debitage in the second Mesolithic and early Neolithic in the north of France (7th and 6th millennium BCE). Journal of Lithic Studies, 4(2): 75-103. doi:10.2218/jls.v4i2.2538

Blanchard, N. \& Forré, P. 2003, Géologie et géographie de l'opale résinite et de l'opalite en Centre-ouest. Feuillets Mensuels de la Société Nantaise de Préhistoire, 411: 34-39. (In French) ("Geology and geography of opal resinite and opalite in the Center-West")

Blanchet, S., Forré, P., Fromont, N., Hamon, C. \& Hamon, G. 2010, Un habitat du Néolithique ancien à Betton « Pluvignon » (Ille-et-Vilaine). Présentation synthétique et premiers résultats. In: Premiers Néolithiques de l'Ouest. Cultures, réseaux, échanges des premières sociétés néolithiques à leur expansion (Billard C. \& Legris M., Eds.), Presses Universitaires de France, Rennes: p. 15-40. (in French) ("An ancient Neolithic settlement in Betton "Pluvignon” (Ille-et-Vilaine). Synthetic presentation and first results")

Charraud, F. 2015, Exploitation minière et gestion des lames en silex du Cinglais au Néolithique ancien: de la minière d'Espins (Calvados) « Foupendant » aux habitats du Nord-Ouest de la France. Bulletin de la Société Préhistorique Française, 112(2): 317338. (in French) ("Mining and management of flint blades from the Cinglais to the early 
Neolithic period: from the Espins (Calvados) "Foupendant" mine to the habitats of North-West France") doi:10.3406/bspf.2015.14523

Clark, J. G. D. 1958, Blade and Trapeze Industries of The European Stone age. Proceedings of the Prehistoric Society, 24(2): 24-42. doi:10.1017/S0079497X00016716

Cordier, G. 1998, L'origine de l'opale résinite utilisée par les Néolithiques des Pays de la Loire: un problème qui s'éclaircit... ou qui se complique ?. Revue Archéologique du Centre de la France, 37: 5-12. (in French) ("The origin of the resinite opal used by the Neolithic people of the Pays de la Loire: a problem which is clarified...or which is complicated?"). URL : https://www.persee.fr/doc/racf_02206617_1998_num_37_1_2786

Desloges, J. 1986, Fouilles de mines à silex sur le site néolithique de Bretteville-le-Rabet (Calvados). Revue Archéologique de l'Ouest, (supplément n¹): 73-101. (in French) ("Flint mine excavations on the Neolithic site of Bretteville-le-Rabet (Calvados)")

Delvigne, V. 2016, Géoressources et expressions technoculturelles dans le sud du Massif central au Paléolithique supérieur: des déterminismes et des choix. Archéologie et Préhistoire. Doctoral thesis at the École doctorale Sciences et Environnements. Université de Bordeaux, Bordeaux, 1287 p. (in French) ("Georesources and technocultural expressions in the south of the Massif Central in the Upper Paleolithic: determinisms and choices") URL: https://tel.archives-ouvertes.fr/tel01326945/document

Delvigne, V., Fernandes, P., Piboule M., Lafarge, A. \& Raynal, J.-P. 2017, Circulation de géomatières sur de longues distances au Paléolithique supérieur: le cas des silex du Turonien du Sud du Bassin parisien. Comptes Rendus Palevol, 16: 82-102. (in French) ("Circulation of geomaterials over long distances in the Upper Paleolithic: the case of Turonian flints from the South of the Paris Basin") doi:10.1016/j.crpv.2016.04.005

Fernandes, P. \& Raynal J.-P. 2006, Pétroarchéologie du silex: un retour aux sources. Comptes Rendus Palevol, 5(6): 829-837. (in French) ("Flint petroarcheology: back to basics") doi:10.1016/j.crpv.2006.04.002

Fouéré, P. 1994, Les industries en silex entre Néolithique moyen et Campaniforme dans le Nord du Bassin aquitain; approches méthodologiques, implications culturelles de l'économie des matières premières et du débitage. Doctoral thesis at the Université de Bordeaux 1, Bordeaux. 547 p. (in French) ("Flint industries between Middle Neolithic and Campaniforme in the North of the Aquitaine Basin; methodological approaches, cultural implications of the economics of raw materials and debitage")

Fromont, N. 2006, Un site d'acquisition du schiste pour la fabrication d'anneaux au Néolithique ancien à Saint-Germain-du-Corbéis « l'Hermitage » (Orne). Bulletin de la Société Préhistorique Française, 103(1): 49-70. (in French) ("An acquisition site for schist for the manufacture of rings in the early Neolithic era in Saint-Germain-duCorbéis "Hermitage" (Orne)") doi:10.3406/bspf.2006.13395

Fromont, N. 2008, Les anneaux du Néolithique bas-normand et du nord Sarthe: production, circulation et territoires, Bulletin de la Société Préhistorique Française, 103(1) : 49-70. (in French) ("The rings of the Lower Norman Neolithic and northern Sarthe: production, circulation and territories ") doi:10.3406/bspf.2008.13705

Ghesquière, E., Marcigny, C., Desloges, J. \& Charraud, F. 2008, Production de lames en silex bathonien dans la plaine de Caen: la redécouverte de la minière des Longrais à 
Soumont-Saint-Quentin (Calvados). INTERNÉO, 7, 103-119. (in French) ("Production of Bathonian flint blades in the Caen plain: the rediscovery of the Longrais mine in Soumont-Saint-Quentin (Calvados)") Accessed 31/10/2020.

URL: http://www.prehistoire.org/offres/file_inline_src/515/515_pj_131216_181653.pdf

Ghesquière, E., Marcigny, C., Giazzon, D., Tsogbou-Ahoupe, R., Charraud, F. \& Juhel, L. 2012, La minière néolithique de RI « Le Fresne » (Orne). In: Roches et Sociétés de la Préhistoire, entre massifs cristallins et bassins sédimentaires (Marchand G., \& Querré G. Eds.). Presses Universitaires de Rennes, Rennes: p. 453-464. (in French) ("The Neolithic mine of RI "Le Fresne" (Orne)")

Giot, P.-R. \& Cogné, J. 1955, Etude pétrographique des haches polies de Bretagne, IV, Les haches de combat en métahornblendite. Bulletin de la Société Préhistorique Française, 52(7): 401-409. (in French) ("Petrographic study of polished axes from Brittany, IV, battle axes in metahornblendite") doi:10.3406/bspf.1955.3226

Giot, P.-R., Hallegouet, B. \& Monnier J.-L. 1977, Le paléolithique supérieur du Pays de Léon (Finistère). Les gisements de Roc'h Toul, Parc ar Plenen (Guiclan), Enez Guennoc (Landéda) et la Forest-Landerneau. L'Anthropologie, 81(2): 201-234. (in French) ("The Upper Paleolithic of the Pays de Léon (Finistère). The Roc'h Toul, Parc ar Plenen (Guiclan), Enez Guennoc (Landéda) and Forest-Landerneau deposits")

Gouletquer, P., Kayser, O., Le Goffic, M., Léopold, P., Marchand, G. \& Moullec, J.-M. 1996, Où sont passés les Mésolithiques côtiers bretons ? Bilan 1985-1995 des prospections de surface dans le Finistère. Revue Archéologique de l'Ouest, 13 : 5-30. (in French) ("Where did the Breton coastal Mesolithic go? 1985-1995 review of surface surveys in Finistère") doi:10.3406/rao.1996.1037

Guyodo, J.-N. 2001, Les assemblages lithiques des groupes néolithiques sur le massif armoricain et ses marges, Doctoral thesis at the Université de Rennes 1, Rennes, 466 p. (in French) ("The lithic assemblages of the Neolithic groups on the Armorican massif and its margins")

Herbaut, F. 2001, La parure néolithique dans l'Ouest de la France. Doctoral thesis at the Université de Nantes, Nantes, 354 p. (in French) ("Neolithic adornment in Western France")

Huet, B. 2006, De l'influence des matières premières lithiques sur les comportements technoéconomiques au Paléolithique moyen: l'exemple du Massif armoricain (France). Doctoral thesis at the Université de Rennes 1, Rennes, 523 p. (in French) ("On the influence of lithic raw materials on techno-economic behavior in the Middle Paleolithic: the example of the Armorican Massif (France)")

Ihuel, E. 2008, De la circulation des grandes lames à la circulation des poignards. Mutation des productions lithiques spécialisées dans l'Ouest de la France du Ve au IIIe millénaire. Doctoral thesis at the Université de Paris X-Nanterre, Nanterre, 394 p. (in French) ("From the circulation of large blades to the circulation of daggers. Mutation of specialized lithic productions in the West of France from the 5th to the 3rd millennium")

Le Roux, C.-T. 1999, L'outillage de pierre polie en métadolérite du type A. Les ateliers de Plussulien (Côtes d'Armor): Production et diffusion au Néolithique dans la France de l'ouest et au-delà. Travaux du Laboratoire "Anthropologie, Préhistoire et Quaternaire Armoricains", n 43, Rennes, 244 p. (in French) ("Tooling of polished metadolerite type 
A. The workshops of Plussulien (Côtes d'Armor): Production and distribution in the Neolithic in western France and beyond")

Marchand, G. 1999, La néolithisation de l'ouest de la France: caractérisation des industries lithiques. British Archaeological Reports International Series Vol. 748. BAR Publishing, Oxford, 487 p. (in French) ("The neolithization of western France: characterization of lithic industries")

Marchand, G. 2005, Les occupations mésolithiques à l'intérieur du Finistère. Bilan archéographique et méthodologique (2001-2003). Revue Archéologique de l'Ouest, 22: 25-84. (in French) ("The Mesolithic occupations in the interior of Finistère. Archaeological and methodological assessment") doi:10.3406/rao.2005.1116

Marchand, G. 2009, The end of Mesolithic in western France: from taphonomy to the understanding of prehistoric territories. In: Mesolithic Horizons (McCartan S., Schulting R., Warren G. \& Woodman P. Eds.), Volume II. Oxford Books, Oxford: p. 507-513.

Marchand, G. 2014, Premier et second Mésolithique: Et au-delà des techniques ? In: Des techniques aux territoires: nouveaux regards sur les cultures mésolithiques (Henry, A., Marquebielle, B., Chesnaux, L., \& Michel, S. Eds.), P@lethnology, Vol. 6, Maison de la recherche, Toulouse: p. 9-22. (in French) ("First and Second Mesolithic: And beyond the techniques?”) URL: http://blogs.univ-tlse2.fr/palethnologie/2014-revue/

Marchand, G., Arthuis, R., Philibert, S., Sellami, F., Sicard, S., Forré, P., Lanoë, S., Nauleau, J.-F., Quesnel, L. \& Querré, G. 2009, Un habitat azilien en Anjou: les Chaloignes à Mozé-sur-Louet (Maine-et-Loire). Gallia-Préhistoire, 51: 1-113. (in French) ("An Azilian settlement in Anjou : les Chaloignes in Mozé-sur-Louet (Maine-et-Loire)") doi:10.3406/galip.2009.2475

Marchand, G. \& Tsobgou Ahoupe, R. 2009, What shall we leave behind? From the mechanical analysis of rocks to stylistic variability in the Mesolithic of Brittany. In: Non-Flint Raw Material Use in Prehistory. Old Prejudices and New Directions (Sternke F., Eigeland L. \& Costa L.-J., Eds.), British Archaeological Reports International Series Vol. 1939. Archaeopress, Oxford, p. 233-240.

Marchand G, Dupont C., Laforge, M., Le Bannier, J.-C., Netter, C., Nukushina, D., Onfray, M., Querré, G., Quesnel, L. \& Stéphan, P. 2018, Before the spatial analysis of Beg-erVil: A journey through the multiple archaeological dimensions of a Mesolithic dwelling in Atlantic France. Journal of Archaeological Science: Reports, 18: 973-983. doi:10.1016/j.jasrep.2017.07.014

Marchand, G. \& Perrin, T. 2017, Why this revolution? Explaining the major technical shift in Southwestern Europe during the 7th millennium cal. BC. Quaternary International, 428: 73-85. doi:10.1016/j.quaint.2015.07.059

Marchand, G., Calvo Gómez, J., Cuenca Solana, D., Henin, A. \& Nukushina, D. 2019, Le macro-outillage en pierre du Mésolithique atlantique: un référentiel bien daté sur l'habitat littoral de Beg-er-Vil (Quiberon, Morbihan), Bulletin de la Société Préhistorique Française, 116(4): 615-656. (in French) ("Atlantic Mesolithic stone macro-tools : a well-dated repository on the coastal habitat of Beg-er-Vil (Quiberon, Morbihan)")

Monnier, J.-L. 1980, Le Paléolithique de la Bretagne dans son cadre géologique. Travaux du Laboratoire d'Anthropologie, Rennes, 597 p. (in French) ("The Paleolithic of Brittany in its geological setting") 
Pailler, Y. 2007, Des dernières industries à trapèzes à l'affirmation du Néolithique en Bretagne Occidentale (5500 - 3500 av. J.-C.). British Archaeological Reports International Series Vol, 1648. John \& Erica Hedges, Oxford, 340 p. (in French) ("From the last trapezoidal industries to the Neolithic affirmation in Western Brittany (5500 3500 BC)")

Pailler, Y., Marchand, G., Blanchet, S., Guyodo, J.-N. \& Hamon, G. 2008, Le VilleneuveSaint-Germain dans la péninsule Armoricaine: les débuts d'une enquête. In: Fin des traditions danubiennes dans le Néolithique du Bassin parisien et de la Belgique (51004700 av. J.-C.). Autour des recherches de Claude Constantin (Burnez-Lanotte, L., Ilett, M. \& Allard, P., Eds.), Société Préhistorique Française et Presses Universitaires de Namur, PUN, Mémoire XLIV de la Société Préhistorique Française, Paris: p. 91-111. (in French) ("Villeneuve-Saint-Germain in the Armorican Peninsula: the beginnings of an investigation ")

Pétrequin, P., Cassen, S., Errera, M., Klassen, L., Sheridan, A., Pétrequin, A.-M. 2012, Jade. Grandes haches alpines du Néolithique européen. Ve et IVe millénaires av. J.-C. Presses Universitaires de Franche-Comté et Centre de Recherche Archéologique de la Vallée de l'Ain, Besançon, 2 tomes: 1536 p. (in French) ("Jade. Large alpine axes from the European Neolithic. 5th and 4th millennium B.C.")

Primault, J. 2003, Exploitation et diffusion des silex de la région du Grand-Pressigny au Paléolithique, In: Les matières premières lithiques en Préhistoire (Surmely F., Ed.), Actes de la Table Ronde Internationale, Préhistoire du Sud-Ouest, supplément n5: p. 283-292. (in French) ("Exploitation and distribution of flint from the Grand-Pressigny region in the Paleolithic")

Primault, J. 2012, Circulations d'objets à grandes distances au Paléolithique. L'exemple des silex tourangeaux et poitevins. In: Roches et Sociétés de la Préhistoire, entre massifs cristallins et bassins sédimentaires (Marchand G., \& Querré G. Eds.). Presses Universitaires de Rennes, Rennes: p. 81-92. (in French) ("Circulation of objects at great distances in the Paleolithic. The example of Touraine and Poitou flints")

Querré, G., Herbault, F. \& Calligaro, T. 2008, Transport of Neolithic variscites demonstrated by PIXE analysis, X-Ray Spectrometry, 37: 116-120. doi:10.1002/xrs.1031

Tsobgou Ahoupe, R. 2006, Chimie, structure de la matière et modalités du débitage des ultramylonites et cataclasites armoricaines: exemple du site mésolithique final de Creac’h Miné Vihan (France). Archéosciences, 30: 109-118. (in French) ("Chemistry, structure of matter and methods of debitage of Armorican ultramylonites and cataclasites: example of the final Mesolithic site of Creac'h Miné Vihan (France)") doi:10.4000/archeosciences. 251

Tsobgou Ahoupe, R. 2007, Matières et techniques de la Préhistoire récente du Massif armoricain: pétrographie-géochimie-mécanique-technologies. Doctoral thesis at the Université de Rennes 1, Rennes, 536 p. (in French) ("Materials and techniques of recent prehistory of the Armorican Massif: petrography-geochemistry-mechanicstechnologies")

Tsobgou Ahoupe, R. 2010, Mapping Mesolithic and Neolithic cultures behaviours and interactions with nature and properties of rocks in Western France. Journal of Archaeological Science, 36(7): 1615-1625. doi:10.1016/j.jas.2009.03.024 
Tsobgou Ahoupe, R. \& Dabard, M.-P. 2010, Petrographical, structural and mechanical analysis of Armorican phtanites: a key raw material for the Mesolithic in Western France. Geoarchaeology, 25(3): 327-351. doi:10.1002/gea.20310

Yven, E. 2003, Kerhuellan (Plusquellec, Côtes d'Armor), un "site-carrière" mésolithique. Revue Archéologique de l'Ouest, 20: 33-51. (in French) ("Kerhuellan (Plusquellec, Côtes d'Armor), a Mesolithic "quarry site")

Yven, E. 2004, Approche spatiale et territoriale des industries lithiques. Constantes et variantes dans l'occupation du substrat géographique et la gestion des matières premières lithiques au Mésolithique en Bretagne, Doctoral thesis at the Université de Bretagne Occidentale, Brest, 726 p. (in French) ("Spatial and territorial approach of lithic industries. Constants and variants in the occupation of the geographical substrate and the management of lithic raw materials in the Mesolithic in Brittany") 